\title{
BUDAYA POLITIK MENGGELITIK, PEREMPUAN TERTARIK GENDER DAN POLITIK DALAM TUBUH PEREMPUAN
}

\author{
Hilyatul Auliya, M.S.I ${ }^{1}$ \\ hilyaliya@gmail.com
}

\begin{abstract}
ABSTRAK
Agama memang menjauhkan kita dari dosa, tapi berapa banyak dosa yang kita lakukan atas nama agama, itulah penggalan pernyataan Kartini. Perkembangan zaman yang serba modern serta bersemilirkan kesetaraan gender, membuat kaum perempuan lebih aktif dalam melakukan setiap hal yang dilakukan oleh kaum laki-laki. Salah satunya dalam dunia politik. Saat ini, banyak kaum perempuan yang ikut andil dalam dunia keberpolitikan.Manfaat perempuan aktif dalam berpartisipasi politik akan dirasakan jika dia dapat mengambil peran dalam berbagai wilayah, baik ranah publik dan domestik. Apalagi jika perempuan bias bahu membahu mengangkat derajatnya dengan tidak menginjak perempuan lain dan tentunya bersama kaum pria yang sadar akan persamaan derajat.
\end{abstract}

\begin{abstract}
Religion does keep us from sin, but how many sins do we do in the name of religion, that's a fragment of Kartini's statement. The development of a modern era and a gender equality, make women more active in doing everything done by men. One of them is in politics. At present, many women are contributing to the world of politics. The benefits of active women in political participation will be felt if they can take roles in various regions, both in the public and domestic spheres. Especially if women can work together to raise their degrees by not stepping on other women and of course with men who are aware of the same degree.
\end{abstract}

${ }^{1}$ Alumni Program Pascasarjana UIN Sunan Kalijaga Yogyakarta. Dosen STAIMA Babakan Ciwaringin Cirebon 


\section{A.Pendahuluan}

Perjalanan perempuan dalam dunia yang patriarkhis, merupakan perjuangan yang sangat melelahkan dan berat. Marjinalisasi perempuan dalam peradaban kuno dapat terlihat pada peradaban Cina, India, Babylonia, Siria, Persia, Romawi, Yunani, Mesir. Kondisi perempuan yang memprihatinkan juga biasanya disebabkan oleh penyimpangan dalam agama. ${ }^{2}$ Limitasi atas gerak perempuan terjadi dalam berbagai lini, baik ruang privat terlebih di ruang publik. Begitu tendensiusnya hegemoni kaum laki-laki terhadap interpretasi teks suci secara tidak langsung melahirkan kebijakan yang cenderung diskriminatif terhadap perempuan. Seiring dengan meningkatnya kesadaran kaum perempuan, maka protes terhadap dominasi kaum laki-laki pun menguat. Wacana kesetaraan genderpun diusung kaum pasangan Adam ini, sebagai protes atas marjinal-isasi eksistensi mereka.

2 Fatimah Umar Nasif, Menggungat Sejarah Perempuan, terj. Burhan W. dan Kundan D.K (Jakarta: Cendikia Sentra Muslim, 2001), hlm. 17-62. Lihat juga sejarah perempuan di Jazirah Arab sebelum kedatangan Islam, Nasaruddin Umar, Argumen Kesetaraan Gender (Jakarta: Paramadina, 1999), hlm. 91134. Walaupun dalam Islam posisi perempuan sangat dihormati, tapi secara realitas tidak berbeda dengan kondisi perempuan yang "terbelenggu" budaya patriarki. Lihat juga Asghar Ali Engineer, Hak-hak Perempuan dalam Islam, (Yogyakarta: LSPPA, 2000), hlm. 29.
Perdebatan mengenai boleh tidaknya perempuan memimpin baik dalam ruang publik maupun privat, merupakan salah satu wacana yang sering diusung dalam kesetaraan gender. Hal ini tidak mengherankan, melihat dalam tilikan sejarahnya perempuan kerapkali dijadikan bahan perdebatan. Meskipun tema yang dibicarakan adalah mengenai hak-hak wanita muslim; nikah, Mahar, dan lain sebagainya, yang notabene wilayah perempun. Namun perempuan sendiri lebih sering diposisikan sebagai objek bukan subjek itu sendiri. ${ }^{3}$ Dan perebutan, meskipun hak-hak politik perempuan sering terabaikan.

Perdebatan tentang hak-hak politik perempuan terbagi dalam tiga pendapat; pertama; pendapat konservatif yang menyatakan bahwa perempuan tidak diperkenankan terjun dalam politik, kedua; pendapat liberal-proresif yang menyatakan bahwa Islam sejak awal memperkenankan perempuan dalam bidang politik, ketiga; pendapat apologetis yang menyatakan ada bagian wilayah politik tertentu yang sama sekali tidak terjamah oleh perempuan, menurut pendapat kelompok ini wilayah politik perempuan adalah menjadi ibu.

3 Asghar Ali Engineer, Islam dan Teologi Pembebasan, (Yogyakarta: Pustaka Pelajar, 1999), hlm. 235. 
Sedangkan hak politik perempuan dalam wacana fiqih kontemporer terbagi menjadi dua; pertama; pendapat dari kalangan fundamentalis, kedua; perempuan sejajar dengan laki-laki. Menurut Laela Ahmad, Women and Gender in Islam: Historical Roots of Modern Debate. ${ }^{4}$

Sehingga perdebatan tersebut tidak pernah akan tuntas dan selalu terkurung dalam bentuk ideologisnormatif yang selalu membawa justifikasi agama, sebuah ironi yang sangat menyedihkan mengingat gerak perempuan merupakan realitas-historis yang tak terbantahkan.

\section{B. Perempuan dalam Ranah Publik}

Dalam konteks Indonesia, titik tolak sejarah kebangkitan perempuan diyakini terjadi pada tahun 1921. Setelah itu, kaum perempuan kemudian melangkah memasuki periode demi priode dalam babakan sejarah, dari perjuangan melawan kolonialisme sampai akhirnya Indonesia meraih kemerdekaan. Ironisnya, kemerdekaan politik untuk bangsa dan negara tersebut belum mampu membentuk tatanan masyarakat yang memposisikan

${ }^{4}$ Dikutip oleh Syafiq Hasyim, Hal-hal yang tak Terpikirkan (Bandung: Mizan, 2001), hlm. 188-195. kaum perempuan dan laki-laki secara sejajar. ${ }^{5}$

Gambaran secara umum akan partisipasi perempuan dalam domain politik di Indonesia memperlihatkan representasi yang minim dalam berbagai lini kehidupan politik; baik pengambilan keputusan ditingkat eksekutif, legislatif, yudikatif, birokrasi pemerintahan, partai politik dan kehidupan publik. ${ }^{6}$ Maka tidak mengherankan bila kebijakan yang lahir pun kurang berpihak kaum pasangan Adam ini. Sebenarnya jika pengambil kebijakan, baik laki-laki maupun perem-puan, sadar akan perlunya kesetaraan gender, maka diharapkan kebijakan yang timpangpun akan bisa dihindarkan, minimal direduksi.

Belum lagi sebagai sebuah aktivitas yang berada dalam domain

${ }^{5}$ Ruth Indiah Rahayu, "Politik Gender Orde Baru; Tinjauan Organisasi Perempuan sejak 1980-an" dalam Liza Hadiz (ed.), Perempuan dalam Wacana Politik Orde Baru, (Jakarta: LP3ES, 2004), hlm. 421-422.

${ }^{6}$ Ani Sucipto, "Perempuan dan Politik di Indonesia" dalam Mursyidah Tahir (ed.) Jurnal Pemikiran Islam tentang Pemberdayaan Perempuan, edisi perdana (Jakarta: PP Muslimat NU dan Logos, 2000), hlm 43. Representasi perempuan dalam DPR RI pada tiap pemilu, dari pemilu 1955-2004, jumlahnya tidak lebih dari $13 \%$, lihat http;//www.cetro.or.id/perempuan/losari,html. Ini sangat ironis mengingat perempuan adalah penduduk mayoritas di Indonesia. Dan representasi tersebut lebih kecil bila dibandingkan dengan Malaysia dan Singapura. Lihat juga Nani Soewondo, Kedudukan Wanita Indonesia, (Jakarta: Ghalia Indonesia, 1984), hlm. 160-161. 
publik, studi politik di Indonesia sangat bias gender. Sinyalemen ini dapat dilihat misalnya, bagaimana budaya dan entitas dinaturalisasi, sementara gender tidak mempertanyakan berbagai narasi politik di Indonesia. Diskursus studi politik di Indonesia dalam enam pendekatan; state - qua-state, bureaucratic polity and patrimonial cluster (negara birokratis dan kelompok patrimonial), bureaucratic pluralism (pluralisme birokratis), bureaucratic-authoritarianism, structuralist approach, dan restricted pluralis (pluralisme terbatas). ${ }^{7}$

Dalam kontestasi politik hal yang menarik adalah adanya keputusan politik bahwa perempuan memiliki kesetaraan pada aktivitas politik yang dituangkan sebagai dasar yuridis dalam UUD $45 .^{8} \mathrm{Hal}$ ini mendapat respons positif dari partai-partai politik peserta pemilu termasuk partai politik yang pada tahun 1999 pernah menolak presiden perempuan. Sungguh menakjubkan bahwa kebijakan affirmative action $30 \%$ quota

7 Ini menunjukkan state oriented, sedangkan kajian terhadap masyarakat sipil sangat sedikit, apalagi studi politik yang menampilkan aktivitas perempuan. Simon Philpott, Meruntuhkan Indonesia, terj. Nuruddin dan Uzair (Yogyakarta: LKiS, 2000), hlm. 108109.

$\begin{array}{llll}8 & \text { Pasal } & 28 & \text { A-J. }\end{array}$ http://www.rahima.or.id/SR/10-03/Tafsir.htm. perempuan ini juga diterima tanpa resistensi dan perdebatan yang berarti bahkan oleh para ulama dan organisasi-organisasi keagamaan garis keras.

Refleksi dari pengalaman sejak tahun 2004 memberi beberapa pembelajaran berharga. Pertama, mitos sisterhood solidarity (solidaritas perempuan). Kedua, dibutuhkan akulturasi proses pembelajaran dan pemaknaan baru bagi kebijakan afirmatif pada masyarakat basis sehingga ada dukungan kultural bagi gagasan tersebut dan isu ini bukan hanya jadi komoditas kelas menengah dan terpelajar di perkotaan. Ketiga, perjuangan kebijakan afirmatif yang seolah-olah diterima publik sebagai isu perempuan dan harus diperjuangkan kelompok perempuan sendiri jika ingin berhasil, dengan menegasikan potensi kekuatan kelompok masyarakat sipil lain, adalah keliru. ${ }^{9}$

\section{Gerakan Sosial dan Perempuan}

Gerakan sosial merupakan salah satu bentuk utama dari perilaku kolektif. $^{10}$ Secara formal

http://www.menegpp.go.id/menegpp.php?cat=d etail\&id=artikel\&dat $=345$.

10 Perilaku kolektif (collective behaviour) merupakan ciri khas dari suatu masyarakat berkebudayaan kompleks, prilaku kolektif sendiri meliputi perilaku kerumunan, prilaku massa dan gerakan sosial. Piotr 
gerakan sosial didefinisikan sebagai suatu kolektivitas yang melakukan kegiatan dengan kadar kesinambungan tertentu untuk menunjang atau menolak perubahan yang terjadi dalam masyarakat atau kelompok yang mencakup kolektifitas itu sendiri.

Gerakan sosial lahir pada mulanya sebagai suatu kelompok orang yang tidak puas dengan keadaan. Gerakan sosial biasanya didefinisikan sebagai gerakan bersama sekelompok orang atau masyarakat yang terorganisir tetapi informal bersifat lintas kelompok untuk menentang atau mendesakkan perubahan.

Banyak versi dan dimensi dari definisi gerakan sosial, misalnya, menekankan pentingnya empat unsur utama, yaitu Pertama, jaringan yang kuat tetapi interaksinya bersifat informal atau tidak terstruktur. Dengan kata lain ada ikatan ide dan komitmen bersama di antara para anggota atau konstituen gerakan itu meskipun mereka dibedakan dalam profesi, kelas sosial, dan lain sebagainya. Kedua, Sharing keyakinan dan solidaritas di antara mereka. Ketiga, ada aksi bersama dengan membawa isu yang bersifat konfliktual. Ini berkaitan dengan

Sztompta, Sosiologi Perubahan Sosial, Terj. Alimandan (Jakarta: Prenada, 2007), hlm. penentangan atau desakan terhadap perubahan tertentu. Keempat, aksi tuntutan itu bersifat kontinyu tetapi tidak terinstitusi dan mengikuti prosedur rutin seperti dikenal dalam organisasi atau agama.

Dengan demikian, bisa diidealkan bahwa gerakan sosial sesungguhnya berangkat dari kesadaran sekelompok orang atas kepentingannya. Meskipun selalu dibutuhkan kepemimpinan di dalam semua gerakan sosial, tetapi keuntungan (value-added) dan capaiannya selalu harus kembali kepada konstituen gerakan dan bukan kepada pemimpinnya.

Tulisan-tulisan tentang gerakan sosial baru di Indonesia cenderung memberikan penekanan pada peran pemimpin dan keuntungan yang hanya kembali kepada mereka. Sedikit sekali, keberhasilan, jika ada, dari gerakan itu langsung memberikan keuntungan kepada konstituennya.

\section{Gerakan Sosial Keagamaan}

Sejarah kelahiran agamaagama tidak dapat dilepaskan dari semangat pembebasan atas belenggu yang diderita manusia pada setiap masanya. Maka kelahiran suatu gerakan dan pemikiran keagamaan selalu dilatarbelakangi oleh situasi dan kondisi yang dirasa tidak 
memuaskan. ${ }^{11}$ Kompleksitas persoalan yang melatar-belakanginya merupakan ekspresi dari Islamisme, aktivisme yang berbendera agama yang sangat rumit dan perwujudan penuntutan reposisi peran Islam dalam ruang diskursif dan landskap politik kenegaraan. Letupan Islamisme mulai memperlihatkan api pengaruhnya pada permulaan abad 20, seiring dengan sistem negara bangsa modern menggantikan sistem kehalifahan, keamiran, dan bentuk-bentuk pemerintahan feodal lainnya yang berbasis kekeluargaan dan kesukuan. Sebagai akibat penerapan sistem negara bangsa, elite-elite politik baru dan kelas sosial ekonomi pendukung mereka bermunculan, menggeser dominsi kaum status quo. Bermula pada 1930-an, Hasan al Banna (1903-1949), pendiri Ikhwan al Muslimin di Mesir, Abul Ala al Maududi (19031978), pencetus partai Jama`at Islami di Pakistan, mem-perkenalkan gerakan pemikiran yang berusaha mendefinisikan Islam sebagai Ideologi Politik, berhadaphadapan dengan ideologi-ideologi politik besar lainnya pada abad ke20. Kedua ideologi tersebut ini melegitimasi visi baru mereka dengan

11 Kamanto Sunarto, Pengantar Sosilogi, Jakarta: LPFE Ekonomi UI, 2000), hlm. 203. merujuk seruan yang telah sebelumnya diperkenalkan oleh Muhammad ibn 'Abd al Wahab (1703-1792) yang lebih dikenal dengan Wahabisme, modern-isme yang digagas oleh Jamaluddin al Afgani (1865-1898), Muhammad Abduh (1849-1905), Muhamad Rasid Rida (1865-1935). ${ }^{12}$

Kehadiran dan perkembangan Islam di Indonesia merupakan fenomena yang sepektakuler, karena berlangsung damai dan kultural. Kehadirannya pun dalam waktu yang bergama. Selain kehadirannya diterima oleh masyarakat, Islam juga menjadi agama resmi kerajaan di berbagai pulau di tanah air. Pada masa penjajahan Islam menjadi kekuatan perlawanan terhadap penjajah, yang melahirkan gerakan perjuangan dalam berbagai pertempuran. Dalam masa kebangkitan Indonesia kemerdekaan, Islam tumbuh menjadi kekutan kebangkitan nasional. Pada era ini lahirlah gerakan-gerakan Islam yang terorganisasi secara modern, yang disebut juga gerakan salfiyah misalnya Muhammadiyah Nopember 1912), Persatuan Islam/Persis (12 September 1923), Al

12 Antony Black, Pemikiran Politik Islam, terj. Abdullah Ali dan Mariana Ariestyawati (Jakarta: Serambi, 2006). John L. Esposito, The Islamic Threat, (Oxford: Oxford University Press, 1999). Lihat juga Jhon Esposito,Islam and Politics (Syracuse: Syracuse University, 1985). 
Irsyad (11 Agustus 1915), dan Serikat Dagang Islam/SDI (16 Oktober 1905) kemudian berubah menjadi Serikat Dagang Islam/SI (11 November 1911), Nahdlatul 'Ulama (1926). Dewan Dakwah Islamiyah Indonesia (20 Februarai 1967).

Menurut Azyumardi $\mathrm{Azra}^{13}$ ada tiga tipologi gerakan keagamaan yang berada di Indonesia; pertama substansialisme; gerakan keagamaan atau simbol-simbol eksplisit tertentu yang berkaitan dengan agama. Dalam konteks kemasyarakatan para pen-dukung paham substitusionalisme Islam lebih konsen pada pengembangan dan penerapan nilainilai Islam secara implisit. Kedua, formalis legalisme yang lebih menekankan pada sifat ekslusif yang hakekatnya inhern dalam setiap agama. Gerakan semacam ini juga terletak pada ketaatan formal dan hukum agama, yang dalam konteks sosial seringkali diekspresikan dalam bentuk label dan simbol keagamaan. Ketiga spiritualisme, paham keagamaan yang lebih menekankan pada pengembangan sikap batiniah, yang dapat melalui keikutsertaan dalam kelompok ekslusif spiritualistik mistik. Dan cenderung bersifat non-politis, maka

\footnotetext{
13 Azyumardi Azra, Konteks berteologi di Indonesia Pengalaman Islam (Jakarta: Paramadina, 1999), hlm. 9.
}

jarang sekali muncul ke permukaan mereka menjadi headlines media masa ketika paham gerakan mereka menyimpang dari paham keagamaan mainstream yang berlaku.

Seiring merebaknya gerakan sosial yang berbasiskan "kepentingan" yang bercorak "maskulinitas" juga lahir dari berbagai badan otonom darinya yang bersifat "feminim". Di kalangan wanita muncul organisasi Putri Mardika di Jakarta (1912), Organisasi Kautaman Istri di Tasikmalaya (1913), Perkumpulan Pawita wanito di Magelang (1915), Wanita Susilo di Pemalang (1918), Wanito Hadi di Jepara (1915). ${ }^{14}$ Wanita Oetomo yang kemudian menjadi Serikat Perempuan Islam Indonesia (SPII), Aisyiah bagian dari Muhammadiyah, Inaituni bagian dari Sarikat Ambon (1920). ${ }^{15}$ Selain organisasi-organisasi tersebut terdapat pula lahir organisasi pemudi-pemudi yang terpelajar.

Pada tanggal 22-25 Desember 1928 diadakan kongres perempuan Indonesia pertama di Yogyakarta, yang dihadiri 30 organisasi perempuan. Hasil kongres tersebut

14 Suhartono, Sejarah Pergerakan Nasional dari Budi Utomo sampai Proklamasi 1908-1945 (Bandung: Pustaka Pelajar, 1994), hlm. 102.

${ }^{15}$ Nani Soewondo, Kedudukan Wanita Indonesia dalam Hukum dan Masyarakat ( Jakarta: Timun Mas, 1968), hlm. 133. 
maka didirikan organisasi PPPI (Perikatan Perkumpulan Perempuan Indonesia). ${ }^{16}$ Selanjutnya kongres ke-2 di Jakarta pada tanggal 20-24 Juli 1935. kongres ke-3 di Bandung pada Juli 1938. Tahun 1940 iklim politik memanas khususnya di Eropa dengan semboyan "Jerman di atas segala-galanya", Hitler menguasai semua bangsa. Untuk itu Belanda sebagai pihak kolonial menekan pemuda Indonesia untuk bergabung dengan pihak Belanda. Maka kongres Wanita ke-4 menolak milis tersebut. Kongres ini sarat dengan keputusan politik karena menyatakan dukungan kepada aksi GAPI (Gabungan Aksi Politik Indonesia) mencanangkan gagasan Indonesia berparlemen, ber-bangsa satu dan berbahasa satu. ${ }^{17}$

Setelah mengalahkan Belanda dalam perang Asia Pasifik pada tahun1945, Jepang mengambil alih pemerintahan di tanah air dan membubarkan semua organisasi masyarakat termasuk organisasi wanita, $^{18}$ namun organisasi bentukan Jepang tak terlepas dari

$1 6 \longdiv { \text { Hajah Idrus Ani, Wanita Dulu, } }$ Sekarang dan Esok (Medan: Pustaka Pelajar, 1980), hlm. 50.

${ }^{17}$ M. C. Ricklefs, Sejarah Indonesia Modern (Yogyakarta: Gajah Mada University Press, 1995), hlm. 253.

${ }^{18}$ Organisasi Wanita bentukan Jepang adalah Fujinkai, yang wilayah kerjanya mengurus dapur umu, mengunjungi tentara yang sakit, dan pemberantasan buta huruf. Lihat Nani Soewondo, Kududukan Wanita ..., hlm. 141. mempersiapkan

kemerdekaan Indonesia. $^{19}$

Tanggal 26 Februari 1946 berdirilah gabungan perkmpulanperkumpulan wanita dan putri dengan nama Kongres Wanita Indonesia (KOWANI) sebagai lanjutan kongres Wanita Indonesia dari masa sebelum perang dunia II. ${ }^{20}$ Sejak tahun 1966, pergerakan wanita Indonesia mengalami perkembangan dan peningkatan yang pesat. Bisa dilihat dari terbentuknya organisasi istri pegawai departemen-departeman atau lembaga pemerintahan. ${ }^{21}$

\section{E. Partisipasi Politik Perempuan}

Pengertian partisipasi politik menurut Samuel $\mathrm{P}$ Huntington adalah sebagai kegiatan warga negara yang bertujuan untuk mempengaruhi pengambilan keputusan

19 Pimpinan Pusat Kongres Wanita Indonesia (KOWANI), Sejarah Pergerakan Perempuan Indonesia; Menggali Aspirasi Masa Lalu, Menyongsong Masa Depan (Yogykarta: PP KOWANI, 1998), hlm. 6.

20 Tahun 1965 Muslimat NU bergabung dengan KOWANI dan peranannya sangat menonjol yang secara khusus dalam mendesak pemerintah untuk membubarkan TK Melati yang dikelola oleh Gerwani/PKI. Lihat Aisyah Hamid Baidlowi, "Profil Organisasi Wanita Islam: Studi Kasus Muslimat NU" dalam Lies Marcoes (ed.), Kumpulan Makalah Seminar Kajian Tekstual dan Kontekstual (Jakarta: INIS, 1993), hlm. 90.

21 Sukanti Suryochondro, Potret Pergerakan Wanita di Indonesia (Jakarta: Rajawali, 1984), hlm. 255. 
oleh pemerintah..$^{22}$ Menurut Ramlan Surbakti partisipasi politik adalah kegiatan warganegara biasa dalam mempengaruhi proses pembuatan dan pelaksanaan kebijak-sanaan umum dan dalam ikut me-nentukan pemimpin pemerintahan. ${ }^{23}$

Cara-cara berpartisipasi memiliki bermacam bentuk dan intensitas. Pembedaan tersebut meliputi jenis partisipasi menurut frekuensi dan intensitasnya. Berbagi jenis partisipasi tergambar dalam piramida. Di antara basis dan puncak terdapat pelbagai kegiatan yang berbeda intesitasnya, berbeda menurut intesitas kegiatan maupun mengenai bobot komitmen dari orang yang bersangkutan. Termasuk di dalamnya memberi sura dalam pemilihan umum, mendiskuskan masalah politik, mengahdiri rapat umum yang bersifat politik menjadi anggota kelompok kepentinan. Yang lebih intensif lagi adalah melibatkan diri dalam pelbagai pekerjaan sosial, contacting atau lobying pejabat, bekerja aktif sebagai anggota dari partai politik atau menjasi juru kampanye, dan yang paling intensif sebagi pimpinan partai atau kelompok kepentingan dan pekerja

\footnotetext{
22 Samuel P. Huntington dan Joan M.

Nelson, Partisipasi Politik di Negara Berkembang (Jakarta: Rineka Cipta, 1990), hlm. 6.

${ }^{23}$ Ramlan Surbakti, Memahami Ilmu Politik (Jakarta: Grasindo, 1992), hlm 118.
}

sepenuh waktu. Dalam hubungan ini menarik untuk disimak bahwa Roth dan Wilson memasukan dalam bagian puncak piramida, the deviant yaitu perilaku menyimpang seperti pembunuhan politik, pembajakan dan teroris.

Piramida Partisipasi Politik meliputi aktovis, partisipan, pengamat dan apolitis. $^{24}$ Aktivis: Menyimpang; pembunuh politik, pembajak, dan teroris, Pejabat umum, pejabat partai sepenuh waktu, pimpinan kelompok kepentingan. Partisipan: Petugas kampanye, aktif dalam partai/kelompok kepentingan. Pengamat: Menhadiri rapat umum, anggota kelompok kepentingan, memberikan suara dalam pemilu, mendiskusikan masalah politik, perhatian pada perkembangan politik.

Kecenderungan ke arah partisipasi politik yang lebih luas sesungguhnya cara-cara yang ditempuh berbagai lapisan masyarakat dalam menuntut hak mereka untuk mendapatkan partisipasi politik yang lebih luas sangatlah berbeda di berbagai negara. Myron Weiner berpandangan bahwa terdapat lima hal yang menyebabkan timbulnya

${ }^{24} \overline{\text { Mariam budiharjo, Partisipasi dan }}$ partai politik (Jakarta: Obor, 1998), hlm. 7 mengutip David F. Roth dan Frank L. Wilson The Cimparative Study of Politic, edisi II (Englewood Cliffs, New Jersy: Prentice Inc, 1980, hlm 151. 
gerakan ke arah partisipasi lebih luas dalam proses politik; meliputi modernisasi, perubahan struktur kelas sosial, pengaruh kamu intelektual, konflik di antara kelompokkelompok politik dan komunikasi masa modern, konflik di antara kelompok-kelompok politik, keterlibatan pemerintah yang luas dalam berbagai bidang. ${ }^{25}$

Bentuk partisipasi politik yang terjadi di berbagai negara dapat dibedakan menjadi kegiatan politik dalam bentuk konvensional dan non-konvensional termasuk yang mungkin legal maupun ilegal. Bentuk-bentuk dan frekuensi partisipasi politik dapat dipakai sebagi ukuran untuk menilai stabilitas sistem politik, integritas ke-hidupan politik, tingkat kepuasan warga negara. Gabriel almond menguraikan bentuk-bentuk partisipasi politik terdiri atas konvensional dan non-konvensioanal: ${ }^{26}$

Konvensional meliputi: pemberian suara, diskusi politik, kampanye, membentuk atau bergabung dalam kelompok kepentingan komunikasi individual dengan pejabat

\footnotetext{
25 Arifin Rahman, Sistem Politik Indonesia dalam Prespektif Struktural Fungsional (Surabaya: SIC, 2002), hlm 130131.

26 Gabriel Almond "Sosialisasi, Kebudayaan dan Partisipasi Politik" dalam Mochtar Mas`oed dan Colin Mic Andrews, Perbandingan Sistem Politik (Yogyakarta: Gadjah Mada University), hlm 32.
}

politik atau administratif. Nonkonvensional Pengajuan petisi, Demonstrasi, Konfrontasi, Mogok, Tindak kekerasan politik, Perang gerilya/revolusi.

Hierarki partisipasi politik ${ }^{27}$ menduduki jabatan politik atau administrasi, mencari jabatan politik atau administrasi, keanggotaan aktif suatu organisasi, keanggotaan pasif suatu organisasi, keanggotaan aktif organisasi semu politik (quasi political), keanggotaan pasif organisasi semu poitik, partisipasi dalam rapat umum, demonstrasi, partisipasi dalam diskusi politik informal, voting (pem-berian suara), dan apatis total (masa bodoh).

Hierarki tersebut dimaksudkan untuk mecakup seluruh jajaran partisipasi politik dan untuk dapat diterapkan pada semua tipe sistem politi. Arti dari berbagai tingkatan ini tentunya mungkin berbeda antara sistem politik dengan sistem politik yang lain dan tingkatan khusus menyebabkan akibat besar pada suatu sistem dan akibat kecil atau tanpa mempunya akibat apapun pada sistem lainnya. Adalah penting juga untuk kita sadari bahwa partisipasi pada satu tingkatan hierarki tidak merupakan prasarat bagi partisipasi pada tingkatan yang lebih tinggi,

27 Michael Rush dan Philip Althof, Pengantar Sosiologi Politik (Jakarta: Rajawali Press, 2005), hlm. 122. 
walaupun mungkin hal itu berlaku bagi tipe-tipe partisipasi tertentu.

Pada puncak hierarki terdapat orang-orang yang menduduki berbagai macam jabatan dalam sistem politik baik para pemegang jabatan poltik maupun anggota birokrasi pada berbagai tingkatan. Mereka itu dibedakan dari partisipasi-partisipasi politik lainnya dalam hal bahwa berbagai taraf mereka berkepentingan dengan pelaksanaan kekuasaaan politik yang formal. Hal ini tidak menghapus pelaksanaan kekuasaan yang sesungguhnya maupun pelaksanaan pengaruh oleh individuindividu atau kelompok-kelompok lain dalam sistem politik. Di bawah para pemegang atau pencari jabatan di dalam sistem politik terdapat mereka yang menjadi anggota dari berbagai tipe organisasi politik atau semu politik. Hal ini mebcakup semua tipe partai politik dan kelompok kepentingan. Dari sudut pandang sistem politik, partai plitik dan kelompok kepentingan dapat diklasifikasikan sebagai agen-agen mobilisasi poloiti. Melalui dua sarana tersebut seorang warga negara dapat berpartisipasi dalam berbagai kegiatan politik.

Perbedaan dasar anatara partai politik dan kelompok kepentingan terletak pada sikap-sikap mereka. Kelimpok kepentingan adalah or- ganisasi yang berusaha memajukan, mempertahankan atau mewakili sikap-sikap yang terbatas atau khas. Selain itu kelompok kepentingan memiliki tujuan-tujuan terbatas seperti introduksi, pencabutan atau perubahan terhadap undang-undang atau peraturan-peraturan tertentu. sedangkan parati politik memiliki orientasi untuk memperoleh dan mempertahankan ke-kuasaan, di samping itu partai politik berusaha untuk memajukan, mem-pertahankan atau mewakili spektrum yang lebih luas, karena itu, istilah organisasi politik yang terdapat dalam hierarki partisipasi politik dimaksudkan mencakup partai politik dan kelopok kepentingan yang rasion detrenya bersifat politis. Sementara istilah quasi political mencakup kelompok-kelompok kepentingan yang berfungsi-nya hanya sebagian saja bersifat politik. Partisipai poltik dalam partai politik dan kelompok kepentingan dapat mengambil bentuk aktif maupun pasif, yang mana tersusun mulai dari menduduki jabatan dalam organisasi sedemikian rupa sampai kepada memberikan dukungan keuangan dengan jalan membayar sumbangan atau iuran keanggotaan.

Dalam hierarki yang digambarkan oleh Michael Rush dan Philip Althoff tersebut dapat ditarik sebah kesimpulan bahwa mereka 
yang benar-benar berpartisipasi dalam bentuk paling tinggi dalam suatu aktivitas politik merupakan minoritas dalam suatu kelompok masyarakat. Satu hal yang tidak boleh dilupakan bahwa dalam membahas partisipasi politik harus pula ada perhatian terhadap mereka yang tidak berpartsipasi sama sekali dalam proses politik. Individuindividu yang demikian dapat dinyatakan sebagi orang-orang yang apatis secara total.

Dalam kaitan hal itu, maka partisipasi politik seseorang dipercaya sangat dipengaruhi oleh sejumlah faktor, di antaranya pendidikan. Di negara-negara maju pendidikan tinggi dapat membuka akses bagi seseorang terhadap informasi tentang persoalan-persoalan politik, kemudian dia dapat mengembangkan kemampuan analisisnya sehingga akhirnya melahirkan minat dan kemampuan berpolitik. Selain itu faktor penting yang mempengaruhi proses partisipasi politik adalah pendapatan, pekerjaan, ras, jenis kelamin, umur, tempat tinggal, situasi, status, dan organisasi. ${ }^{28}$

Pembahasan Partisipasi Politik Perempuan di indonesiia memperlihatkan reprsentasi yang rendah dalam semua tingkatan pengambilan

$28 \overline{\text { Mariam mengutip Saymour Martin }}$ Lipset, Political Man: The Sosial Bases of Politics (Bombay ...). keputusan, baik ditingkat eksekutif, legislatif, yudikatif, partai politik, dan kehidupan publik lainnya. Selain rendahnya representasi perempuan dalam bidang politik, seakan-akan perempuan hanya memainkan peranan sekunder. ${ }^{29}$

Peran politik formal perempuan merupakan fenomena menarik sehingga memunculkan wacana polemik yang berkepanjangan dalam rangka mencari format yang baku. Melalui format yang baku tersebut diharapkan perempuan dapat berperan secara optimal dalam kancah perpolitikan nasional. Kemudian rendahnya representasi politik perempuan juga dapat dilihat dari berbagai indikator atau varianvarian politik antara lain keanggotaan perempuan dalam MPR.

Pentingnya keterwakilan perempuan dalam politik tidak hanya demi kekuasaan politik yang lebih beradab, tanpa kekerasan. Komitmen kebangsaan dan tanggungjawab untuk membangun demokrasi yang dimiliki oleh perempuan Indonesia, hendaknya menjadi dapat menjadi modal bagi pembentukan rasa kebangsaan dan karakter bangsa ini. Maka patutlah perempuan tampil sebagi pengambil keputusan politik

\footnotetext{
${ }^{29} \overline{\text { Siti Musdah Mulia dan Anik Farida, }}$ Perempuan dan Politik (Jakarta: Gramedia, 2005), hlm 16-17.
} 
dala rangka membangun sistem politik nasional yang berkeadilan.

Upaya perempuan untuk melepaskan jeratan terali besi kultural kaum laki-laki telah memasuki tahapan yang paling menentukan. Tuntutan tradisional yang hanya sebatas menuntut kesetaraan dalam status sosial ekonomi, telah berubah menjadi tuntutan yang lebih moderen. Tuntutan moderen dimanifestasikan ke dalam bentuk kesetaraan dalam hal peng-ambilan keputusan stratejik dalam bidang politik.

Kaum perempuan ingin 'bermain' dalam bidang politik karena didasari oleh suatu dalil, bahwa melalui bidang politiklah segala kebijakan yang ber-sentuhan dengan masalah publik (baca: wanita) dapat dibuat secara proporsional. Secara implisit bermakna, perempuan harus merubah tatanan kehidupan bermasyarakat dan bernegara melalui partisipasi dalam pembuatan kebijakan publik.

Suatu kesadaran baru yang merupakan akumulasi dari serentetan perjuangan yang pernah dilakukan kaum perempuan. Sinyal keberhasilan tersebut berupa pemberian kuota 30 persen untuk perempuan di lembaga legeslatif. Dengan harapan perempuan dapat merubah mengeliminasi kebijakan publik yang selama ini cenderung bercorak maskulin.

Gerakan perempuan yang pernah ada di Indonesia mulai dari kongres perempuan sampai dengan lahirnya Gerwani dan Wanita Marhaen masih bermuara kepada kelompok penekan. Kelompok ini bertujuan untuk memperjuangkan kesetaraan gender. Hal ini berarti bahwa Gerwani dan Wanita Marhaen atau dalam era reformasi muncul gerakan Ibu Peduli masuk dalam kategori kelompok sosial biasa. Kelompok sosial dalam perjuangannya hanya berkisar pada kepentingan kemasyarakatan. Perjuangan untuk mendapatkan kesataraan gender ini pun merupakan isu sosial belaka, bukan urusan politik.

Untuk itu, perlu diluruskan kembali pemahaman tentang perjuangan kelompok sosial dan kelompok politik. Meskipun sebagai subjek dan objek yang sama, ke dua kelompok tersebut akan bersinggungan dalam satu titik bernama kelompok sosial politik. Ketika wanita atau perempuan memperjuangkan kepentingan sosial politiknya, maka wadah formal mereka bisa dikategorikan ke dalam kelompok sosial politik. Perjuangan mereka pun bermuara kepada pemenuhan kebutuhan sosial politik seperti keterlibatan dalam politik 
formal, pem-buatan kebijakan publik, proaktif terhadap pelaksanaan sistem politik yang ada, dan sebagainya.

Peran perempuan dalam tiap ranah sangat termarjinalkan apalagi dalam wilayah politik. Hal ini mendorong para para pengambil kebijakan untuk menetapkan peraturan yang peka terhadap perempuan. Misalnya UU pemilu no 12/2003 pasal 65 ayat 1: "Setiap partai politik peserta pemilu dapat mengajukan calon anggota DPR, DPRD propinsi dan DPRD Kabupaten/Kota untuk setiap daerah pemilihan dengan mem-perhatikan keterwakilan perempuan sekurangkurangnya 30\%." Walaupun UU tersebut bisa menjadi senjata bagi perempuan tapi AD/ART partai politik belum tentu juga memperhatikan perempuan, karena kata-kata "dapat" diartikan hanya semacam anjuran sehingga partai politik tidak berkewajiban untuk memenuhi kuota tersebut. ${ }^{30}$

Untuk itu perempuan harus bersaing dengan laki-laki, karena dunia politik didominasi laki-laki. Perempuan juga akan terganjal masalah administrasi, kebijakan partai politik, dan finansial.

$30 \quad$ Naning Mardiyanah dkk, Memperkuat Posisi Politik Rakyat (Jakarta: CESDA-LP3ES, 2004), hlm. 130.
Agar bisa mencapai cita-cita politik, perempuan dalam politik, perempuan selain harus menjadi yang aktif juga harus terlibat dalam lembaga politik. Untuk melihat struktur ke-sempatan dan peluang di partai politik, ada dua hal yang perlu dipelajari. Pertama, landasan legal formal yang merupakan pedoman untuk melakukan kegiatan seharihari partai maupun untuk mengataur sepak terjang partai dalam melaksanakan fungsi-funsi politiknya. Dan hal ini tercantum dalam anggaran dasar dan anggaran rumah tangga (AD/ART) Partai politik. Kedua pandangan yang direfleksikan oleh para petinggi partai politik atau kebijakan yang dihasilkan oleh partai politik melalui musyawarah nasional partai. ${ }^{31}$

\section{F. Penutup}

Manfaat perempuan aktif dalam berpartisipasi politik akan dirasakan jika dia dapat mengambil peran dalam berbagai wilayah, baik ranah publik dan domestik. Apalagi jika perempuan bias bahu membahu mengangkat derajatnya dengan tidak menginjak perempuan lain dan tentunya bersama kaum pria yang sadar akan persamaan derajat.

31 Ani Soetjipto, Politik Perempuan Bukan Gerhana: Esai-Esai Pilihan (Jakarta: Kompas, 2005), hlm. 65. 
Kaum perempuan seharusnya memaksimalkan energi politik dan sosial untuk kembali menggerakkan isu ini. Politisi perempuan diperlukan kontribusi maksimalnya melalui perjuangan mereka di partai, lintas partai, dan pada institusi politik seperti parlemen. Isu bersama saat ini, bukan kuota sebagai tujuan tetapi bagaimana menggunakan kuota dan avirmatif sebagai instrumen mencapai tujuan dan merespons persoalan sosial masyarakat.

Selama perjuangan kaum perempuan hanya dilakukan melalui kelompok penekan di luar parlemen, maka kepentingan mereka mustahil dapat terpenuhi dan bisa mengangkat derajad kaum perempuan itu sendiri di ranah publik.

Perlakuan yang diskriminatif dan bermuara kepada ketidakadilan yang akhirnya mematikan partisipasi politik formal kaum perempuan. Tetapi sekali lagi, bahwa kemarahan kaum perempuan terhadap perlakuan diskriminatif tersebut memang memicu lahirnya gerakan perempuan, namun hanya sesaat.

Kesinambungan dan kontinuitas gerakan politik perempuan masih lemah. Akibatnya, perjuangan mereka akan mudah patah dan akhirnya mati. Di sini kaum perempuan memang gagal mengikatkan tali komitmen yang kuat di antara pegiat gerakan politik perempuan.

Terlepas dari uraian di atas, selanjutnya yang perlu dimatangkan oleh kaum perempuan setelah mendapat kesempatan berpolitik secara formal adalah membuktikan perannya alam hal ini dalam domain publik. Kesempatan berpartisipasi politik formal kaum perempuan perlu didukung dan diapresiasi secara wajar. Bagi perempuan, kesempatan ini jangan diartikan sebagai arena balas dendam, karena selama ini menjadi objek maskulinitas politik laki-laki.

Sungguhpun jika kebikanan dari negara terhadapan perempuan dalam berkiprah di dunia politik sudah ada dan perempuan sudah siap berlaga namun peratungan di intern dan ekstern partai politik memerlukan pengerahan strategi yang luar biasa, karena tingkat pertarungannya juga tak bisa ditanya.

Bagi seorang perempuan, ketika sudah memilih ranah publik, aktif diberbagai kegiatan bahkan menjadi pelopor digerakkan sosial tak akan mampu bertarung jika partai politiknya hanya memanfaatkanya sebagai syarat sahnya saja. Karena "musuh" ada dalam nyata maumpun tak nyata, pria dan wanita, dalam komplotan dan grombolan. Bahkan kebijakan, apakah kau siap, wahai perempuan? 


\section{DAFTAR PUSTAKA}

Lies Marcoes ed. 1993. Kumpulan Makalah Seminar Kajian Tekstual dan Kontekstual. Jakarta: INIS.

Ani Soetjipto. 2005. Politik Perempuan Bukan Gerhana: Esai-Esai Pilihan. Jakarta: Kompas.

Ani Sucipto. 2000. "Perempuan dan Politik di Indonesia" dalam Mursyidah Tahir ed. Jurnal Pemikiran Islam tentang Pemberdayaan Perempuan. Edisi perdana Jakarta: PP Muslimat NU dan Logos.

Antony Black. 2006. Pemikiran Politik Islam. Terj. Abdullah Ali dan Mariana Ariestyawati. Jakarta: Serambi.

Arifin Rahman. 2002. Sistem Politik Indonesia dalam Prespektif Struktural Fungsional. Surabaya: SIC.

Asghar Ali Engineer. 2000. Hak-hak Perempuan dalam Islam. Yogyakarta: LSPPA.
Asghar Ali Engineer. 1999. Islam dan Teologi Pembebasan. Yogyakarta: Pustaka Pelajar.

Azyumardi Azra. 1999. Konteks Berteologi di Indonesia Pengalaman Islam. Jakarta: Paramadina.

Fatimah Umar Nasif. 2001. Menggungat Sejarah Perempuan. Terj. Burhan W. dan Kundan D.K. Jakarta: Cendikia Sentra Muslim.

Hajah Idrus Ani. 1980. Wanita Dulu, Sekarang, dan Esok. Medan: Pustaka Pelajar.

Jhon Esposito. 1985. Islam and Politics. Syracuse. Syracuse University.

John L. Esposito. 1999. The Islamic Threat. Oxford: Oxford University Press.

Kamanto Sunarto. 2000. Pengantar Sosilogi. Jakarta: LPFE Ekonomi UI.

Liza Hadiz ed.2004. Perempuan dalam Wacana Politik Orde Baru. Jakarta: LP3ES. 
M. C. Ricklefs. 1995. Sejarah Indonesia Modern. Yogyakarta: Gajah Mada University Press.

Mariam Budiharjo. 1998. Partisipasi dan Partai Politik. Jakarta: Obor.

Michael Rush dan Philip Althof. 2005. Pengantar Sosiologi Politik. Jakarta: Rajawali Press.

Mochtar Mas`oed dan Colin Mic Andrews. Perbandingan Sistem Politik. Yogyakarta: Gadjah Mada University.

Nani Soewondo. 1968. Kedudukan Wanita Indonesia dalam Hukum dan Masyarakat. Jakarta: Timun Mas.

Nani Soewondo. 1984. Kedudukan Wanita Indonesia. Jakarta: Ghalia Indonesia.

Naning Mardiyanah dkk. 2004. Memperkuat Posisi Politik Rakyat. Jakarta: CESDA-LP3ES.

Nasaruddin Umar. 1999. Argumen Kesetaraan Gender. Jakarta: Paramadina.

Pimpinan Pusat Kongres Wanita Indonesia KOWANI. 1998. Sejarah Pergerakan Perempuan Indonesia; Menggali Aspirasi
Masa Lalu. Menyongsong Masa Depan. Yogykarta: PP KOWANI.

Piotr Sztompta. 2007. Sosiologi Perubahan Sosial. Terj. Alimandan. Jakarta: Prenada.

Ramlan Surbakti. 1992. Memahami Ilmu Politik. Jakarta: Grasindo.

Samuel P. Huntington dan Joan M. Nelson. 1990. Partisipasi Politik di Negara Berkembang. Jakarta: Rineka Cipta.

Simon Philpott. 2000. Meruntuhkan Indonesia. Terj. Nuruddin dan Uzair Yogyakarta: LKiS.

Siti Musdah Mulia dan Anik Farida. 2005. Perempuan dan Politik. Jakarta: Gramedia.

Suhartono. 1994. Sejarah Pergerakan Nasional dari Budi Utomo sampai Proklamasi 1908-1945. Bandung: Pustaka Pelajar.

Sukanti Suryochondro. 1984. Potret Pergerakan Wanita di Indonesia. Jakarta: Rajawali.

Syafiq Hasyim. 2001. Hal-hal yang tak Terpikirkan. Bandung: Mizan. 
http://www.menegpp.go.id/menegpp.p $\underline{\mathrm{hp}}$ ?cat $=$ detail $\& \mathrm{id}=\operatorname{artikel} \&$ dat $=34$

$\underline{5}$.

http://www.rahima.or.id/SR/10-

03/Tafsir.html 